\title{
EXECUTIVE COMPENSATION, GREENHOUSE GAS EMISSIONS DISCLOSURE AND FIRM VALUE
}

\author{
Dian Agustia1)*, Irawan Purwa Wijaya ${ }^{2)}$ \\ ${ }^{1,2}$ Universitas Airlangga, Indonesia
}

\begin{abstract}
This study aims to determine the effect of executive compensation on firm value through greenhouse gas emissions disclosure as a mediation variable. Population in this research are firms listed in the Indonesia Stock Exchange (IDX) and published sustainability reports for the period 2015 to 2019. This study uses quantitative data. A sampling of this research using purposive sampling method and obtained 150 companies. The data analysis technique in this research is using Partial Least Square (PLS) test. This study shows that executive compensation has a significant positive effect on firm value but does not affect greenhouse gas emissions disclosure. Greenhouse gas emissions disclosure has no significant effect on firm value. This research contributes to the relationship of literature about the greenhouse gas emissions being able to mediate partially the effect of executive compensation on firm value. Furthermore, it also addresses greenhouse gas emission and executive compensation using company samples and periods that have not been explored previously.
\end{abstract}

Keywords: Greenhouse gas emissions disclosure, executive compensation and firm value

\section{INTRODUCTION}

Climate change is a global problem that has significant impacts on economic, social and environmental aspects of life. Greenhouse gas emissions are proven to be a major cause of global climate change (Depoers, Jeanjean, \& Jérôme, 2016). Human activity is a major cause of increased greenhouse gas emissions that cause climate change (Lai, 2014; Luo, Lan, \& Tang, 2012). Climate change is altering the order of natural systems in the world, such as changes in the distribution and intensity of rainfall, increased frequency of flooding and prolonged drought (Amran, Periasamy, \& Zulkafli, 2014).

Climate change that is not handled appropriately will threaten the sustainability of human life and affect business activities in the future. Industrial activity accounts for nearly half of the world's total greenhouse gas emissions derived from the combustion process, both during production and construction activities (World Resources Institute, 2014). In 2018 in Indonesia there was one of the environmental phenomena associated with greenhouse gas emissions, namely forest fire events. This prompted the Government of Indonesia to issue legal and regulatory tools, namely the National Action Plan on Reducing Home Gas Emissions as outlined in Peraturan Presiden No. 61/2011 and Invetarisasi GRK through Peraturan Presiden No. 71/2011. The Indonesian government has committed to voluntarily reduce greenhouse gas emissions by $26 \%$ by its own efforts and $41 \%$ with international support until 2020 .

Companies in the world respond to this sustainability issue related to greenhouse gas emissions, currently, companies need to implement strategies and take action to disclose greenhouse gas emissions information. It aims to disclose information related to the company's commitment in reducing the carbon footprint of business activities based on existing disclosure guidelines both government regulations and reporting frameworks from non-governmental agencies (Halkos \& Skouloudis, 2016; Lee, Park, \& Klassen, 2015). Until now the disclosure of greenhouse gas emissions in Indonesia is still voluntary disclosure. Guidelines used for

*Corresponding Author email address: dian.agustia@,feb.unair.ac.id 


\section{AFEBI Accounting Review (AAR)}

\section{Volume 6, No 01 (2021)}

calculating corporate greenhouse gas emissions in Indonesia are in accordance with the $\mathrm{CO} 2$ protocol adopted from the World Business Council for Sustainable Development-World Resource Institute (WBCSD-WRI) (Irwhantoko \& Basuki, 2016).

The urgency gives an idea that the greenhouse gas emission of the company's activities is something that must be considered. Companies are required to disclose information to qualified stakeholders to demonstrate commitment related to environmental issues (Akbaş \& Canikli, 2019). The ongoing report is a means of disclosure of voluntary greenhouse gas emissions that are popular in Asian countries, especially Indonesia. This research plays a role in providing empirical evidence that disclosure of greenhouse gas emissions is able to improve the image and reputation of the company because increased transparency will be assessed well by the public, customers, investors, and other stakeholders.

Companies deal with increasing pressure from stakeholders to measure, reduce and report the greenhouse gas emissions they produce from operations because they have a significant impact on increasing greenhouse gas emissions globally (Amran et al., 2014; Guenther, Guenther, Schiemann, \& Weber, 2016). To respond to this, more and more companies in the world are implementing strategies and taking action to disclose information on greenhouse gas emissions and reduce their carbon footprint using a variety of existing disclosure guidelines, both government regulations and reporting frameworks from non-governmental organizations (Halkos \& Skouloudis, 2016; Lee et al., 2015).

Greenhouse gas emissions are a potential cause for information asymmetry because stakeholders outside the company cannot easily obtain credible information about a company (Akbaş \& Canikli, 2019). Disclosure of greenhouse gas emissions is an effective way for companies to prove that they are able to meet community expectations for a better environment and thus the company will gain legitimacy from the community (Deegan, 2002; Hahn \& Lülfs, 2014; Hahn, Reimsbach, \& Schiemann, 2015). Disclosures relating to the company's environmental information are still voluntary, unaudited, and unregulated (Mathews, 1984). Disclosure of greenhouse gas emissions is a way for companies to publish the amount of greenhouse gas emissions produced as well as information on the amount of reduction in greenhouse gas emissions as a result of climate mitigation policies by companies. Companies that disclose greenhouse gas emissions from business activities tend to experience an increase in the value of the company.

Matsumura, Prakash, and Vera-Munoz (2014), Liu, Zhou, Yang, and Hoepner (2017) and D. Li, Huang, Ren, Chen, and Ning (2018) state that disclosure of greenhouse gas (carbon) emissions has a positive effect on firm value. The disclosure provides benefits in the form of reducing information asymmetry between the company and stakeholders including investors and customers. Increased transparency of information to the public can be assessed by stakeholders so as to increase the value of the company. But research from Cooper, Raman, and Yin (2018), Griffin, Lont, and Sun (2017) and Saka and Oshika (2014) shows that the disclosure of greenhouse gas emissions has a negative effect on firm value.

Firm value is also influenced by the amount of compensation received by company executives. Through an effective contract approach, compensation is able to resolve agency problems that occur between shareholders and management. The management compensation scheme was formed as an effort to achieve goals that are in line with the directors and owners of the company, as well as being able to motivate directors to continue to work actively in increasing the value of the company. Dodonova and Khoroshilov (2014), Upneja and Ozdemir (2014) and Subekti and Sumargo (2015) found that executive compensation had a positive 


\section{EXECUTIVE COMPENSATION, GREENHOUSE GAS EMISSIONS DISCLOSURE}

AND FIRM VALUE

effect on firm value. Research from Chung, Judge, and Li (2015) stated that executive compensation negatively affects the value of the company in Taiwan, because there is a special relationship between the commissioners and directors in the company. Based on the results of previous studies, researchers conducted studies related to the disclosure of greenhouse gas emission as a mediating variable on executive compensation and firm value.

This study aims specifically to determine whether the variable disclosure of greenhouse gas emissions is able to mediate the effect of executive compensation on firm value. Stakeholders want companies to disclose information not only reports of financial performance, but environmental performance reports. Commitment to the environment requires more effort for executives in taking policies. Management commitment to the disclosure of environmental information including the creation of conformity between the values built by management with social values, increasing the company's reputation, showing strong management principles and social responsibility to the community. Compensation is one of the motivations for management to further issue its ability to improve company performance through good information disclosure practices. Transparency Information on the use of emissions disclosed can reduce the occurrence of information asymmetry related to social and environmental aspects so that it can increase the value of the company.

Companies that reveal the quality of greenhouse gas emissions resulting from management commitment to environmental issues in increasing company value. Annual Executive Compensation received is able to increase the value of the company because stakeholders see this as a signal that their commitment to revealing the greater greenhouse gas emissions item. The urgency is the foundation of this study using disclosure of greenhouse gas emissions as mediation in the effect of executive compensation on increasing the value of the company. The results of this study are expected, it can first be useful for company executives to understand the importance of disclosure of greenhouse gas emissions and its influence on the value of the company. Second can be useful for the Government of Indonesia that the urgency of climate change caused by greenhouse gas emissions needs a joint commitment and regulation that regulates all activities that have a direct impact on social and environmental

\section{LITERATURE STUDY}

\subsection{Legitimacy Theory}

The legitimacy theory states that a business operates in the midst of society where there is a social contract between business organizations and the community so that the company can operate and continue to survive (Lehman, 1983). The social contract between the company and the community creates a moral obligation for the company to be socially responsible even though the main objective of the company is to make a profit. Increased public awareness about environmental issues puts great pressure on companies to be more responsible for the environment resulting from operational activities, especially in industries that are seen as damaging to the environment such as mining and energy. To manage this pressure, companies must disclose their emission information and publicize activities that they have undertaken widely to the public to maintain a good reputation and maintain their market share (Delmas \& Toffel, 2004).

Legitimacy theory illustrates that the company is part of a broad social system. Basically, legitimacy theory is based on the concept of a social contract between companies and society. The existence of a company must gain the trust of the community in order to be sustainable. High legitimacy pressure on environmental improvement, especially clean air from 


\section{AFEBI Accounting Review (AAR)}

\section{Volume 6, No 01 (2021)}

stakeholders, should be the concern of executives to make a good disclosure report on greenhouse gas emissions with the aim of getting recognition from the public that a company is able to contribute to the environment so that the sustainability of a company can be maintained. This theory emphasizes that disclosure of greenhouse gas emissions is an effective way for companies to prove that they are able to meet people's expectations for a better environment and thus companies will gain legitimacy from the community. When companies are able to meet public expectations, they gain legitimacy and achieve a good image in the eyes of investors. This will cause the value of the company to increase. Executive compensation is used as a tool to motivate corporate executives to further enhance their capabilities and invest in environmentally friendly technologies to disclose greenhouse gas emissions to gain legitimacy from stakeholders.

\subsection{Agency Theory}

According to Ross (1973) an agency relationship occurs when the principal delegate's authority includes making decisions on agents to perform certain tasks on their behalf. Meanwhile, according to Jensen and Meckling (1976) agency relationships arise when one or more individuals (principals) provide rewards in the form of salary/compensation to other individuals (agents) to act on their behalf. Agency problems often arise when the agent's actions are not in line with the interests of the principal. The agent is motivated to maximize the compensation he receives, whereas principals have the main objective to maximize returns on the resources they have commited. So that conflicts of interest between the two parties cannot be avoided (Jensen \& Meckling, 1976). In addition to the conflict of interest problem, there are other problems that arise as a result of the agency relationship, namely the difficulty or the high cost of the principal determining what management has done in managing the company. This can lead to information asymmetry.

According to agency theory executive compensation can be an effective means of aligning goals between company owners and management so that management focuses on increasing the value of the company with its managerial capabilities. Based on research from Bebchuk and Fried (2003), compensation arrangements received by executives become a means of resolving agency problems. The company's board of directors needs to design a compensation scheme as the optimal contracting approach in order to provide incentives to executives/management with the aim of maximizing shareholder value.

\subsection{Greenhouses Gas Emissions Disclosure}

The company is subjected to social pressure due to environmental problems posed by its activities. To avoid pressures and legal actions that could reduce the company's performance and value, companies must take into account externalities such as pollution and greenhouse gas emissions generated by their activities. Disclosures relating to the company's environmental information are still voluntary, unaudited, and unregulated (Mathews, 1984). Disclosure of greenhouse gas emissions is a way for companies to publish the amount of greenhouse gas emissions produced as well as information on the amount of reduction in greenhouse gas emissions as a result of climate mitigation policies by companies. Disclosure of greenhouse gas emissions is a voluntary disclosure type, and environmental disclosure issue that has been investigated in differences in national contexts and can be seen in the company's annual reports and ongoing reports (Cho, Patten, \& Roberts, 2014). 


\section{EXECUTIVE COMPENSATION, GREENHOUSE GAS EMISSIONS DISCLOSURE}

AND FIRM VALUE

Companies that choose not to disclose their greenhouse gas emissions are less likely to experience a decline in corporate value. This is a sign that executives are failing to integrate the issue of climate change into the business strategy thereby reducing the value of the company (Matsumura et al., 2014). Voluntary disclosure is widely able to improve corporate governance. Increased transparency provides easy access to information to people outside the company and shareholders to monitor the performance and manner of management decision-making, thereby reducing information as valuation becomes more effective (Chung et al., 2015). Goldman and Slezak (2006) and Singh (2006) stated that the CEO plays a big role in determining which information will be published so that the quality or not of the information is determined by the CEO. He and Fang (2016) and Y. Li, Gong, Zhang, and Koh (2018) states that when executives receive greater compensation, their initiatives in building the company's image through improving the quality of environmental information are getting stronger.

Stakeholders want companies to disclose information not only financial performance statements, but environmental performance reports. This aims that the company seeks to legitimize stakeholders related to the company's activities that have contributed to environmental issues. Companies are facing increasing pressure from stakeholders to reduce and report on greenhouse gas emissions they produce from operations because they have a significant impact on rising greenhouse gas emissions globally (Amran et al., 2014; Guenther et al., 2016). The role of the CEO of the company has the ability to influence the quality of the company's information to be disclosed. He and Fang (2016) stated that when executives receive excessive compensation, it will make them more initiative in building the company's image in a responsible way through improving the quality of environmental information. Companies that disclose quality greenhouse gas emissions are generated by management's commitment to environmental issues in increasing the company's value.

\subsection{Hypothesis Development}

\subsubsection{The influence of Executive Compensation on Greenhouse Gas Emission Disclosures}

Company executives have an important role as policymakers, especially in deciding what information will be published through reporting each year. The amount of compensation received by executives can be a motivation to increase their ability and commitment to meet stakeholder expectations so that environmental sustainability can be maintained through better air quality in the future (Goldman \& Slezak, 2006; Singh, 2006). Previous research from He and Fang (2016) and D. Li et al. (2018) states that the amount of annual compensation received by company executives has a positive effect on the disclosure of environmental information which includes aspects of greenhouse gas emissions. Executives committed to the environment are getting better when they receive greater compensation. The first hypothesis of this study is: $\mathrm{H}_{1}$ : Executive compensation has a positive effect on the disclosure of greenhouse gas emissions

\subsubsection{The Influence of Greenhouse Gas Emission Disclosures on Firm Value}

The practice of disclosing greenhouse gas emissions by companies is seen by stakeholders as an effort to meet their expectations for environmental sustainability. It is hoped that the company will also focus on improving air quality. Disclosure of greenhouse gas emissions can also increase investor confidence in a company because of their commitment to meet the expectations of the community. Research from Matsumura et al. (2014) and Liu et al. (2017) states that disclosure of greenhouse gas (carbon) emissions has a positive effect on firm 


\section{Volume 6, No 01 (2021)}

value. D. Li et al. (2018) found that the broader the environmental disclosure of a company, the more that investors will be interested in investing which then increases the value of the company. Based on this statement, the second hypothesis of this study is:

\section{$\mathrm{H}_{2}$ : Disclosure of greenhouse gas emissions has a positive effect on firm value}

\subsubsection{The Influence of Executive Compensation on Firm value}

To increase firm value, owners and executives must have the same goal orientation. Compensation becomes an effective tool to equalize the goals of executives and company owners or shareholders. The amount of compensation is able to make the executive release his technical ability to work so that the value of the company which is reflected in the share price can rise. Previous research from Dodonova and Khoroshilov (2014), Upneja and Ozdemir (2014) and Subekti and Sumargo (2015) stated that executive compensation has a positive effect on firm value. Executive compensation is intended to motivate management to release their technical capabilities so that they can produce results in the form of an increase in the value of a company. Based on the statement above, the third hypothesis of this study is:

\section{$\mathrm{H}_{3}$ : Executive compensation has a positive effect on firm value}

\subsubsection{The Influence of Executive Compensation on Firm value by Disclosure of Greenhouse Gas Emissions as Mediating Variable}

The amount of annual compensation received by company executives is able to increase their initiative and motivation to build a corporate image that can increase firm value. Dodonova and Khoroshilov (2014), Upneja and Ozdemir (2014) and Subekti and Sumargo (2015) stated that executive compensation has a positive effect on firm value. Compensation can be an effective tool so that the desire of the owner to increase the company's value can be realized. Stakeholders also pressure companies to pay more attention to environmental sustainability, especially greenhouse gas emissions as a result of the company's operational activities. The large amount of annual compensation received by the company is a motivational tool for executives to spend more effort to realize the disclosure of greenhouse gas emissions to the public. Previous studies from He and Fang (2016) and D. Li et al. (2018) state that the amount of annual compensation received by company executives has a positive effect on the disclosure of environmental information which includes aspects of greenhouse gas emissions. Disclosure of greenhouse gas emissions requires knowledge, technology and more commitment from policymakers in the company to be able to meet stakeholder expectations. Matsumura et al. (2014) and Liu et al. (2017) state that disclosure of greenhouse gas (carbon) emissions has a positive effect on firm value. D. Li et al. (2018) found that the broader the environmental disclosure of a company, the more that investors will be interested in investing which then increases the value of the company. When stakeholder expectations can be met, this can increase the company's reputation and will increase the value of the company. Based on these descriptions, the researchers propose a fourth hypothesis, namely:

\section{H4: Disclosure of greenhouse gas emissions mediates the relationship of executive compensation and firm value}

\section{RESEARCH METHODOLOGY}

This research is used a quantitative approach because it places more emphasis on testing hypotheses, using measurable data, and producing conclusions that lead to generalizable results. This study uses secondary data obtained from several sources related to this study. The data used is sourced from sustainability reports that use guidelines from the Global Reporting 
Initiative (GRI) and annual reports of companies listed on the Indonesia Stock Exchange (BEI) for the 2015-2019 period. The determination of the population of this research is based on the commitment of the Government of Indonesia voluntarily in 2020 to reduce greenhouse gas emissions by $26 \%$ with its own efforts and $41 \%$ with international support (Kementerian Lingkungan Hidup dan Kehutanan, 2016). Disclosure of greenhouse gas emissions in Indonesia is still voluntary. This disclosure is still being disclosed in the sustainability report. Guidelines for Greenhouse Gas Emission Items and Sustainability Reports are based on the Global Reporting Initiative (GRI). The total sample of the study was 150 companies selected by the purposive sampling method. The criteria for taking the sample of this study include 1) Companies that issue sustainability reports using indicators from GRI between 2015-2019; 2) Companies from all sectors except financial institutions and banks and 3) Companies that do not present complete data related to this research. Data analysis techniques in this study are descriptive statistics, Pearson correlation test, partial least square (PLS) as well as direct hypothesis testing and indirect hypothesis testing.

The independent variable in this study is executive compensation which is proxied by the natural logarithm of the total annual compensation received by the board of commissioners and directors (Chung et al., 2015).

\section{Executive compensation $=\mathbf{L n}$ (number of executive compensation + number of director compensation)}

The dependent variable in this study is the firm's value which is proxied by the yearend stock price (firm market value) (Epstein, Elkington, \& Herman, 2018; Fernandez-Feijoo, Romero, \& Ruiz, 2016). The mediating variable in this study is the disclosure of greenhouse gas emissions measured using indicators issued by the Global Reporting Initiative (GRI). The calculation of the area of disclosure of greenhouse gas emissions is done by giving a score on each item of disclosure on a dichotomous scale. If a company discloses an item on the GRI greenhouse gas emission indicator list then it is given a score of 1, and if not given a score of 0 (Prado-Lorenzo, Gallego-Alvarez, \& Garcia-Sanchez, 2009). This score is then summed and compared with the total items disclosed of greenhouse gas emissions that should be reported according to the GRI indicator.

Disclosure of greenhouse gas emissions $=\frac{\text { number of items disclosed }}{\text { maximum number of items disclosed }}$

Table 3.1

GRI Indicator

Indicators for Disclosure of Greenhouse Gas Emissions

GRI G3

EN16 Total direct and indirect greenhouse gas emissions are measured by weight

EN17 Other indirect greenhouse gas emissions are measured by weight

EN18 Initiatives to reduce greenhouse gas emissions and their achievements

GRI G3.1

EN16 The amount of direct and indirect greenhouse gas emissions measured by weight

EN17 Other relevant and indirect greenhouse gas emissions measured by weight 
EN18 Initiatives to reduce greenhouse gases and successful reductions

\section{GRI G4}

\begin{tabular}{cl}
\hline G4-EN15 & Direct greenhouse gas emissions \\
\hline G4-EN16 & Indirect greenhouse gas emissions \\
\hline G4-EN17 & Other indirect greenhouse gas emissions \\
\hline G4-EN18 & The intensity of greenhouse gas emissions \\
\hline G4-EN19 & Reduction of greenhouse gas emissions \\
\hline GRI Standards & \\
\hline $\mathbf{3 0 5 - 1}$ & Direct greenhouse gas emissions \\
\hline $\mathbf{3 0 5 - 2}$ & Indirect greenhouse gas emissions \\
\hline $\mathbf{3 0 5 - 3}$ & Other indirect greenhouse gas emissions \\
\hline $\mathbf{3 0 5}-4$ & The intensity of greenhouse gas emissions \\
\hline $\mathbf{3 0 5 - 5}$ & Reduction of greenhouse gas emissions \\
\hline
\end{tabular}

Source: GRI Sustainability Reporting Guidelines

The control variables in this study are profitability (ROE), company size (SIZE) and company age (AGE) for which measurements are made as follows:

1) Profitability is proxied by the ratio of return on equity (ROE) measured by dividing net income by equity.

2) The size of the company is measured by the natural logarithm of the company's total assets

3) The age of the company is calculated by the number of years t reduced by the year in which the company makes an initial public offering on the IDXIt describes the research design used comprises of methods, technique in collecting data, technique of data analysis, and variables measurement which are written in paragraphs, not numbering. The technical information of the study presented clearly. Therefore, readers can conduct research based on the techniques presented. Materials and equipment specifications are necessary. Approaches or procedures of study together with data analysis methods must be presented.

\section{RESULT AND DISCUSSION}

The population in this study is companies listed on the Indonesia Stock Exchange and published sustainability reports using the 2015-2019 Global Reporting Initiative guidelines. The objects in this study consist of the variables studied, namely firm value as the dependent variable, executive compensation as an independent variable, and disclosure of greenhouse gas emissions as a mediating variable. The 2015-2019 period was chosen to obtain valid and relevant results so as to be able to represent the relationship between variables as a whole.

Figure 4.1 Direct Relationship Before Given Mediation Variables

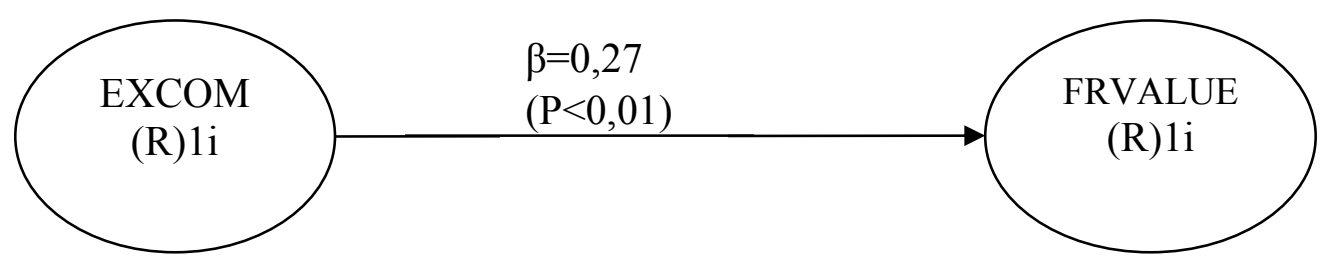


Based on Figure 4.1, there is a positive and significant effect between executive compensation (EXCOM) on firm value (FRVALUE) before being given mediation variables. This is evidenced by a path coefficient of 0.27 and a p-value smaller than the significance level (0.05), which is 0.01 . The existence of a positive value on the path coefficient indicates a unidirectional relationship between executive compensation (EXCOM) and firm value (FRVALUE). This indicates that the higher the executive compensation (EXCOM) value, the firm's value (FRVALUE) also increases. Therefore, H3 is accepted.

Figure 4. 2 Indirect Result

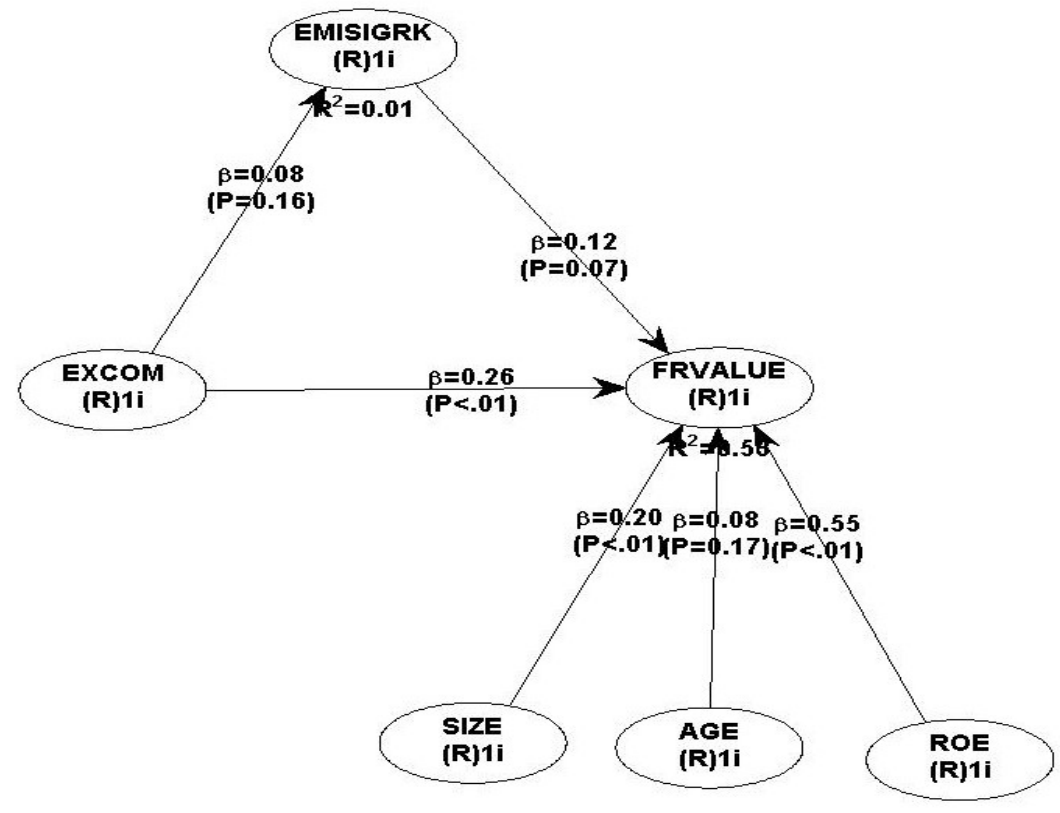

Figure 4.2 shows that:

1) Executive compensation has an insignificant effect on the disclosure of greenhouse gas emissions as seen from the path coefficient of 0.08 and the p-value that exceeds the significance level $(0.05)$ of 0.16 so that $\mathrm{H} 1$ is rejected;

2) Disclosure of greenhouse gas emissions has no significant effect on firm value which can be observed through the path coefficient of 0.12 and p-value that exceeds the significance level of 0.07 so that $\mathrm{H} 2$ is rejected;

3) Executive compensation has a positive effect on firm value as seen from the path coefficient of 0.26 and p-value less than the significance level of 0.01 so that $\mathrm{H} 3$ is accepted;

4) Disclosure of greenhouse gas emissions is proven to mediate some of the direct effects between executive compensation and firm value. These results are evidenced by the decrease in path coefficient on the direct effect between executive compensation on the value of the company before being given a mediating variable by 0.27 and being 0.26 after being given a mediating variable; also the p-value before giving a significant mediating variable by 0.01 and after given mediation variables remain significant with p-value 0.01 . Because it refers to Hair, Ringle, and Sarstedt (2013) that mediation variable decision making in terms of various criteria, namely (1) if the path coefficient between independent variables to the dependent variable shows a fixed value, then a variable is declared unable to provide a mediating effect, (2) If the path coefficient between independent variables towards the dependent variable shows a value that remains significant and only decreases, 


\section{AFEBI Accounting Review (AAR)}

\section{Volume 6, No 01 (2021)}

then a variable is declared capable of partially mediating, and (3) If the path coefficient between the independent variable to the dependent variable becomes insignificant, then a variable is declared capable of mediating in a manner overall (full mediation). So it can be concluded in this study that the disclosure of greenhouse gas emissions mediates some of the effects of executive compensation on firm value. The following table of indirect effect test results, as follows:

This study also uses three control variables, namely company size (SIZE), profitability (ROE), and company age (AGE). Company size (SIZE) value is not significant to firm value. This is evidenced by the p-value less than the significance level (0.05), which is $<0.01$, and the path coefficient of 0.2 . The greater the size of the company, the more it is able to attract investors to invest so as to increase the value of the company. Investors appreciate that companies that have a larger amount of assets will give them greater profits or returns on what they have invested. Larger amounts of assets can be used by companies to maximize shareholder value. High market interest to invest in this company is able to increase the value of the company (Qiu, Shaukat, \& Tharyan, 2016).

Profitability (ROE) has a positive effect on firm value, indicating that a higher company's profit ratio can increase the value of the company. This is evidenced by the $p$-value less than the significance level (0.05), which is $<0.01$, and the path coefficient value is 0.55 . Investors consider that the higher the profitability ratio, the company's ability to generate profits is also high. The greater the company's ability to generate profits, the greater the returns investors will obtain. This will increase investor interest to invest in companies with high profitability which can then increase the value of the company. The results of this study are in line with research from Matsumura et al. (2014).

The company age variable (AGE) has no significant effect on firm value. This is evidenced by the p-value that exceeds 0.05 which is 0.17 with a path coefficient of 0.08 . The results of this study are in line with research from (George \& Kabir, 2012). The longer companies listed on the Indonesia Stock Exchange do not provide guarantees for investors to be more interested in investing in a company. This is because investors do not see that the company has been on the IDX as a guarantee that their financial performance is getting better. Investors see financial performance more than how long the company has been on the IDX. Discussion on the results of hypothesis testing follows.

\subsection{The Influence of Executive Compensation on Greenhouse Gas Emission Disclosure}

Executive compensation has no significant effect on the extent of disclosure of company greenhouse gas emissions. The total annual salary received by company executives in Indonesia is not an effective tool to increase the motivation and commitment of company executives as policymakers to mobilize and improve their ability to disclose greenhouse gas emissions. To practice the disclosure of greenhouse gas emissions requires more technical expertise from management, high costs, and special technology to make it happen (Hermalin \& Weisbach, 2012; Merkl-Davies, Brennan, \& McLeay, 2011).

Disclosure of greenhouse gas emissions requires the ability of more human resources, high costs and special technology to make it happen. Regulations from the government regarding voluntary disclosure of greenhouse gas emissions also contribute to the company management's awareness of the importance of disclosing low levels of greenhouse gas emissions to the public. Commitment to the environment requires more effort for executives in making policies. The amount of compensation for corporate executives in Indonesia is not able 
to motivate them to increase the extent of disclosure of greenhouse gas emissions to the public. This is due to the nature of disclosure that is still voluntary so that management allocates its resources to other aspects such as financial performance.

Companies in developing countries tend to be less active in disclosing information about reducing voluntary greenhouse gas (carbon) emissions compared to companies in developed countries. This happens because of limited financial resources to invest in the use of environmentally friendly technologies and energy, reduce greenhouse gas emissions, and adjust to the effects of global warming. These limitations occur because company policies in developing countries prioritize meeting the financial growth target rather than investing in matters related to pollution prevention (Luo et al., 2012).

\subsection{The Influence of Greenhouse Gas Emission Disclosure on Firm Value}

Disclosure of greenhouse gas emissions has no significant effect on firm value. Deegan (2004), Qiu et al. (2016) and Deswanto and Siregar (2018) state that environmental disclosures which include aspects of disclosure of greenhouse gas emissions do not affect the company's market value. Investors see that disclosure of greenhouse gas emissions by the company has not provided benefits in the form of direct returns on the capital invested in the company.

The impact of the company's operations that produce greenhouse gas emissions has not been considered by investors in making decisions in the capital market. This is because investors see that the disclosure of greenhouse gas emissions by the company has not provided direct benefits to the capital invested in the company. Environmental reporting rules, especially voluntary greenhouse gas emissions, are also a reason for stakeholders, especially investors, to not consider the aspect of disclosure of greenhouse gas emissions in company reports. The government's role in making stricter rules on the disclosure of greenhouse gas emissions can change the way stakeholders assess a company, which is expected to be a major consideration in the aspect of disclosure of greenhouse gas emissions, especially in investment decisions.

Disclosure of greenhouse gas emissions in Indonesia using the GRI indicator does not reflect the responsibility or efforts to prevent environmental damage by the company as a whole. Disclosure of greenhouse gas emissions is only one of many aspects of the disclosure that are part of environmental disclosure according to GRI indicators. The results of this study are in line with research from Deegan (2004); Qiu et al. (2016) and Deswanto and Siregar (2018).

\subsection{The Influence of Executive Compensation on Firm Value}

Executive compensation has a positive effect on firm value. The greater the total annual compensation received by the company's executives, the higher the value of the company, which is proxied by the stock price. Dodonova and Khoroshilov (2014), Upneja and Ozdemir (2014) and (Subekti \& Sumargo, 2015) state that executive compensation has a positive effect on firm value. The results of this study indicate that the greater the annual compensation received by the executive, the higher the company's stock price. This is caused, the amount of compensation received by the company's management makes them motivated and highly committed to meeting the expectations of shareholders who want to maximize their investment returns.

In accordance with agency theory, the compensation received by company executives who act as agents becomes an effective tool for company owners as principals to be able to align goals. Compensation is able to reduce conflicts of interest between agents and principals which if not resolved properly can cause the financial targets that have been formulated to be 


\section{AFEBI Accounting Review (AAR)}

\section{Volume 6, No 01 (2021)}

hampered. Executive compensation has also proven capable of resolving these conflicts of interest so that the financial targets desired by the principal can be achieved. When the conflict of interest can be resolved, the goals of the company owner who wishes to increase the value of the company can be achieved.

\subsection{The Influence of Executive Compensation on Firm value by Disclosure of Greenhouse Gas Emissions as Mediation Variable}

Disclosure of greenhouse gas emissions qualifies as a mediating variable, because the path coefficient has decreased from before being given a mediating variable (direct effect) of 0.27 to 0.26 after being given a mediating variable (indirect effect) and the p-value before being given a significant mediating variable by 0.01 and after being given a mediating variable to remain significant at 0.01 . Greenhouse gas emissions disclosure is proven to be able to partially mediate the effect of executive compensation on company value.

Company executives play an important role in determining what information will be conveyed to the public through the reports it makes. The information to be published should be an effective form of communication for the public to meet stakeholder expectations. The pressure of high legitimacy on environmental improvement, especially clean air from stakeholders, should be the concern of executives to make a good greenhouse gas emission disclosure report with the aim of gaining recognition from the public that a company is able to contribute to the environment so that the sustainability of a company can be maintained. This statement is supported by He and Fang (2016) and Y. Li et al. (2018) stating that compensation given to executives can be an effective tool to motivate them to exert their ability to improve the quality of environmental information, especially greenhouse gas emissions through sustainability reports or annual report

Disclosure of greenhouse gas emissions through continuous or annual reports can foster the confidence of stakeholders, especially investors and shareholders. Increasing transparency of information to the public, especially regarding environmental aspects of greenhouse gas emissions, can reduce the pressure of legitimacy and foster investor confidence. Increased trust from investors is then able to increase the value of the company which is reflected in stock prices. This is due to the shifting of goals: originally the company's main goal is to maximize profits, but now the company is expected to have an active contribution to the environment, especially air quality that affects the sustainability of life. This part should describe informative results of empirical research which are written systematically and critically. Tables and figures can be presented in this part to support the discussion, for examples table of statistics-test results, figures of model test results and etc. In general, journal papers will contain three-seven figures and tables. Same data cannot be presented in the form of tables and figures.

\section{CONCLUSION}

The increase in the amount of compensation received by company executives does not affect the extent of disclosure of greenhouse gas emissions items for reporting to stakeholders. Then, the wider disclosure of house gas emissions does not affect the increase or decrease in the value of the company as proxied by stock prices. Furthermore, the greater the amount of annual compensation received by the company's executives, the greater their motivation and commitment to using their ability to increase the value of the company, and this will have a positive impact on the increase in the company's stock price. Lastly, disclosure of greenhouse gas emissions through sustainability or annual reports is able to foster trust from stakeholders, 


\section{EXECUTIVE COMPENSATION, GREENHOUSE GAS EMISSIONS DISCLOSURE}

AND FIRM VALUE

especially investors and shareholders. This is because the role of disclosure of greenhouse gas emissions can influence company executives in determining the information to be conveyed to stakeholders in obtaining stakeholder legitimacy and trusted.

The limitation in this study is that according to the results of the coefficient of determination test, it shows that the independent variable executive compensation is able to show a direct influence on the mediating variable of greenhouse gas emission disclosure only $1 \%$, so the remaining $99 \%$ is explained by other variables outside this study such as stakeholder pressure. interests, institutional ownership, board gender diversity, company performance, and so on. There are still companies that do not present executive compensation data in the company's annual report so that this study cannot be used as a sample and the disclosure of greenhouse gas emissions is proven not to be a mediation, so there are still variables outside of this study that is able to mediate. The effect of executive compensation on firm value can be used as material for further research.

\section{REFERENCES}

Akbaş, H. E., \& Canikli, S. (2019). Determinants of voluntary greenhouse gas emission disclosure: An empirical investigation on Turkish firms. Sustainability, 11(1), 107.

Amran, A., Periasamy, V., \& Zulkafli, A. H. (2014). Determinants of climate change disclosure by developed and emerging countries in Asia Pacific. Sustainable Development, 22(3), 188-204.

Bebchuk, L. A., \& Fried, J. M. (2003). Executive compensation as an agency problem. Journal of economic perspectives, 17(3), 71-92.

Cho, C. H., Patten, D. M., \& Roberts, R. W. (2014). Environmental disclosures and impression management. In Communication and language analysis in the corporate world (pp. 217231): IGI Global.

Chung, H., Judge, W. Q., \& Li, Y.-H. (2015). Voluntary disclosure, excess executive compensation, and firm value. Journal of Corporate Finance, 32, 64-90.

Cooper, S. A., Raman, K., \& Yin, J. (2018). Halo effect or fallen angel effect? Firm value consequences of greenhouse gas emissions and reputation for corporate social responsibility. Journal of Accounting and Public Policy, 37(3), 226-240.

Deegan, C. (2002). Introduction: The legitimising effect of social and environmental disclosures-a theoretical foundation. Accounting, Auditing \& Accountability Journal.

Deegan, C. (2004). Environmental disclosures and share prices - a discussion about efforts to study this relationship. Paper presented at the Accounting Forum.

Delmas, M., \& Toffel, M. W. (2004). Stakeholders and environmental management practices: an institutional framework. Business Strategy and the Environment, 13(4), 209-222.

Depoers, F., Jeanjean, T., \& Jérôme, T. (2016). Voluntary disclosure of greenhouse gas emissions: Contrasting the carbon disclosure project and corporate reports. Journal of Business Ethics, 134(3), 445-461.

Deswanto, R. B., \& Siregar, S. V. (2018). The associations between environmental disclosures with financial performance, environmental performance, and firm value. Social Responsibility Journal.

Dodonova, A., \& Khoroshilov, Y. (2014). Compensation and performance: An experimental study. Economics Letters, 124(2), 304-307.

Epstein, M. J., Elkington, J., \& Herman, B. (2018). Making sustainability work: Best practices in managing and measuring corporate social, environmental and economic impacts: Routledge. 


\section{Volume 6, No 01 (2021)}

Fernandez-Feijoo, B., Romero, S., \& Ruiz, S. (2016). The assurance market of sustainability reports: What do accounting firms do? Journal of Cleaner Production, 139, 1128-1137.

George, R., \& Kabir, R. (2012). Heterogeneity in business groups and the corporate diversification-firm performance relationship. Journal of Business Research, 65(3), 412-420.

Goldman, E., \& Slezak, S. L. (2006). An equilibrium model of incentive contracts in the presence of information manipulation. Journal of Financial Economics, 80(3), 603-626.

Griffin, P. A., Lont, D. H., \& Sun, E. Y. (2017). The relevance to investors of greenhouse gas emission disclosures. Contemporary Accounting Research, 34(2), 1265-1297.

Guenther, E., Guenther, T., Schiemann, F., \& Weber, G. (2016). Stakeholder relevance for reporting: explanatory factors of carbon disclosure. Business \& Society, 55(3), 361397.

Hahn, R., \& Lülfs, R. (2014). Legitimizing negative aspects in GRI-oriented sustainability reporting: A qualitative analysis of corporate disclosure strategies. Journal of Business Ethics, 123(3), 401-420.

Hahn, R., Reimsbach, D., \& Schiemann, F. (2015). Organizations, climate change, and transparency: Reviewing the literature on carbon disclosure. Organization \& Environment, 28(1), 80-102.

Hair, J. F., Ringle, C. M., \& Sarstedt, M. (2013). Partial least squares structural equation modeling: Rigorous applications, better results and higher acceptance. Long range planning, 46(1-2), 1-12.

Halkos, G., \& Skouloudis, A. (2016). Exploring the current status and key determinants of corporate disclosure on climate change: Evidence from the Greek business sector. Environmental Science \& Policy, 56, 22-31.

He, L., \& Fang, J. (2016). CEO overpayment and dismissal: The role of attribution and attention. Corporate Governance: An International Review, 24(1), 24-41.

Hermalin, B. E., \& Weisbach, M. S. (2012). Information disclosure and corporate governance. The journal of finance, 67(1), 195-233.

Irwhantoko, I., \& Basuki, B. (2016). Carbon emission disclosure: Studi pada perusahaan manufaktur Indonesia. Jurnal Akuntansi dan Keuangan, 18(2), 92-104.

Jensen, M. C., \& Meckling, W. H. (1976). Theory of the firm: Managerial behavior, agency costs and ownership structure. Journal of financial economics, 3(4), 305-360.

Kementerian Lingkungan Hidup dan Kehutanan. (2016). [Press release]. Retrieved from http://www.menlhk.go.id/

Lai, J. H. (2014). Mandatory reporting of greenhouse gas emissions from buildings: Stakeholders' opinions in Hong Kong. Energy Policy, 75, 278-288.

Lee, S. Y., Park, Y. S., \& Klassen, R. D. (2015). Market responses to firms' voluntary climate change information disclosure and carbon communication. Corporate Social Responsibility and Environmental Management, 22(1), 1-12.

Lehman, C. (1983). Stalemate in corporate social responsibility research. American accounting association public interest section.

Li, D., Huang, M., Ren, S., Chen, X., \& Ning, L. (2018). Environmental legitimacy, green innovation, and corporate carbon disclosure: Evidence from CDP China 100. Journal of Business Ethics, 150(4), 1089-1104.

Li, Y., Gong, M., Zhang, X.-Y., \& Koh, L. (2018). The impact of environmental, social, and governance disclosure on firm value: The role of CEO power. The British Accounting Review, 50(1), 60-75.

Liu, Y., Zhou, X., Yang, J., \& Hoepner, A. G. (2017). Corporate carbon emissions and financial performance: Does carbon disclosure mediate the relationship in the UK? Available at SSRN 2941123. 
Luo, L., Lan, Y. C., \& Tang, Q. (2012). Corporate incentives to disclose carbon information: Evidence from the CDP Global 500 report. Journal of International Financial Management \& Accounting, 23(2), 93-120.

Mathews, A. F. (1984). Internal Corporate Investigations. Ohio St. LJ, 45, 655.

Matsumura, E. M., Prakash, R., \& Vera-Munoz, S. C. (2014). Firm-value effects of carbon emissions and carbon disclosures. The accounting review, 89(2), 695-724.

Merkl-Davies, D. M., Brennan, N. M., \& McLeay, S. J. (2011). Impression management and retrospective sense-making in corporate narratives. Accounting, Auditing \& Accountability Journal.

Prado-Lorenzo, J. M., Gallego-Alvarez, I., \& Garcia-Sanchez, I. M. (2009). Stakeholder engagement and corporate social responsibility reporting: the ownership structure effect. Corporate Social Responsibility and Environmental Management, 16(2), 94107.

Qiu, Y., Shaukat, A., \& Tharyan, R. (2016). Environmental and social disclosures: Link with corporate financial performance. The British Accounting Review, 48(1), 102-116.

Ross, S. A. (1973). The economic theory of agency: The principal's problem. The American economic review, 63(2), 134-139.

Saka, C., \& Oshika, T. (2014). Disclosure effects, carbon emissions and corporate value. Sustainability Accounting, Management and Policy Journal.

Singh, R. (2006). Incentive compensation and the quality of disclosure. Available at SSRN 574281.

Subekti, I., \& Sumargo, D. K. (2015). Family management, executive compensation and financial performance of Indonesian listed companies. Procedia-Social and Behavioral Sciences, 211, 578-584.

Upneja, A., \& Ozdemir, O. (2014). Compensation practices in the lodging industry: Does top management pay affect corporate performance? International Journal of Hospitality Management, 38, 30-38.

World Resources Institute. (2014). Climate Analysis Indicators Tool (CAIT) 2.0. . Retrieved from http://cait2.wri.org 